\title{
TWO COTTOID FISHES FROM MONTEREY BAY, CALIFORNIA.
}

\author{
By Charles H. Gilbert, \\ Of Stanford Dniversity, California.
}

The two Cottoid fishes here noted are new to Monterey Bay and one of them represents an undescribed species. The material was collected and donated by Mr. Frederick Woodworth, and was taken with a small boat dredge in shallow water near the shore.

\section{ENOPHRYS TAURINUS, new species.}

Plate 11, fig. 1.

Type.-A specimen $64 \mathrm{~mm}$. long, dredged in shallow water in Monterey Bay, near Pacific Grove, California. Cat. No. 75064, U.S.N.M.

Measurements in hundredths of length without caudal fin: Length of head, 48; greatest depth of body, 31 ; least depth of caudal peduncle, 6.5 ; length of snout, 12.5 ; diameter of eye, 14 ; interorbital width, 7 ; length of maxillary, 17.5; length of preopercular spine, 21 ; length of occipito-nuchal ridge, 18 ; length of opercular ridge, 11 ; length of pectoral fin, 30; length of ventral fin, 19.

Most closely related to E. claviger, with which it agrees in the high compressed snout and the small mouth, in the presence of a band of fine prickles above the lateral line, and in the absence of the lengthwise median plate between the nuchal ridges, which is present in E. bison. It differs from E. claviger in the shorter, more robust preopercular spine, and from both claviger and bison in the reduced number of rays in the dorsal and anal fins. Ten specimens of $E$. bison from Puget Sound have the fin rays as follows:

\begin{tabular}{|r|r|r|r|r|r|r|}
\hline & Dorsal spines. & \multicolumn{2}{|c|}{ Dorsal rays. } & \multicolumn{2}{|c|}{ Anal rays. } \\
\cline { 2 - 6 } & VIII & IX & 11 & 12 & 8 & 9 \\
\hline Specimens................... & 8 & 2 & 6 & 4 & 3 & 7 \\
\hline
\end{tabular}

Proceedings U. S. National Museum, Vol. 47-No. 2049. 
In $E$. claviger, the fin rays are still more numerous, 5 specimens from Bering Sea examined by us having the dorsal VIII-14, and the anal with 11 or 12 rays. In both type and cotype of E. taurinus, the dorsal rays are VII-9, the anal rays 7 .

The orbital region is compressed and high, strongly arched above the occipital and the nasal regions. Interorbital space concave, the occipital region more deeply so. Anterior profile nearly vertical. Mouth small, the maxillary reaching vertical from front of pupil. Eye large, its diameter about twice the interorbital width, equaling the length of the snout. Nasal spines strong in the type, the nasal bones sculptured. Preorbital with two strongly protruding spinous processes in the young type, these little marked in the adult cotype. Upper preopercular spine robust, reaching well beyond the opercular margin; the usual three strong spines below it. Opercular ridge very high, rough-granular. All exposed bones of head finely granular. A single short filament at tip of maxillary, the cotype with a papilla or undeveloped filament anteriorly at its base. Teeth fine, in broad bands in the jaws, a narrow band on the vomer, the palatines naked. A short slit behind the fourth gill-arch. Isthmus very wide, equaling the distance separating the two pectoral fins.

Plates of the lateral line higher than long, those anteriorly with a sharp lengthwise crest, which becomes rounded in the posterior scutes. The lateral line opens principally in a single minute pore above each plate and a similar one below it, but occasionally more than one such pore is present, especially in the anterior part of body. The space between the lateral line and the base of the dorsal is covered with fine prickles, more evident in the young than in adults. The anus is but little in advance of the first anal ray, not reached by the tips of the ventral fins.

Upper parts olive or olive-brown, marbled or mottled with lighter, and with scattered small blackish brown spots. Under parts light, a white streak below middle of sides sending irregular incursions into the darker area above, this more noticeable in the adult specimen. A double dark bar below the soft dorsal, one encircling caudal peduncle below, a dark blotch at base of lower caudal rays. Pectoral with a dusky basal area which intensifies posteriorly to form a brown bar on middle of fin; beyond that a broad white bar, the terminal area of fin with a second narrow brown bar or with small brown spots. In the cotype, the entire lower side of head is dusky.

In addition to the type, a specimen $160 \mathrm{~mm}$. long, here designated a cotype, is in the collection of Stanford University, from Albatross station 2893, in the Santa Barbara Channel, southern California, depth 145 fathoms. The dorsal spines of this specimen have been injured, but can be counted without possibility of error, and the other fins are intact. 
ORTHONOPIAS TRIACIS Starks and Mann.

Plate 11, fig. 2.

Orthonopias triacis Starks and Mann, Univ. of Cal. Pub. Zool., vol. 8, 1911, p. 11, fig. 1.

This species has been known heretofore only from the type-specimen, taken in shallow water on Cortez Banks, near San Diego. A second specimen is here recorded from Monterey Bay, where it was taken by a dredge at a depth of a few fathoms only.

$$
\text { D. IX-16; A. } 12 ; \text { P. } 15 ; \text { V. I, } 3 .
$$

Lateral line with a series of 38 scales, the upper and the posterior margins of which are wholly free and are throughout very finely toothed. In Astrolytes, only a part of the posterior margin is exposed and this is faintly or not at all toothed. In Axyrias, both margins are exposed and are serrulate, though less so than in Orthonopias. Axyrias and Astrolytes are not very well separated, for while Axyrias has typically a simply furcate preopercular spine, occasional examples develop a third tooth, as is always the case in Astrolytes. If this character is disregarded, there is nothing essential to distinguish the two genera. Orthonopias is also very closely related, but may claim a certain distinction in the location of the anus, which is placed well forward near the base of the ventral fins, while in the other two genera mentioned it is almost immediately in advance of the first anal ray.

The longest oblique series of scales in the dorso-lateral band contains 14 scales, while several others contain 13. A very narrow naked strip intervenes between this band and the base of the second dorsal, and even this is partly filled with small spinous scales lying at the base of the dorsal rays, one or two to each ray.

The cirri are somewhat differently disposed than in the type. The four forming a line on top of head behind each eye are present, but the one behind eye is lacking. There is one on each nasal spine, and one or two on each of the three lower preopercular spines. The two on tip of maxillary are as described, and two are present closely apposed on posterior opercular angle. There is one on shoulder, behind the opercular angle, and several others scattered along the length of the lateral line.

This species was set aside as new prior to its publication by Starks and Mann, and the figure then prepared is here reproduced. The first two dorsal spines are here represented as much shorter than those which follow. As this was apparently not true of the type, it may in this specimen be due to injury, although the fin has not that appearance. 


\section{$2 \mathrm{BHL}$ Biodiversity Heritage Library}

Gilbert, Charles H. 1914. "Two cottoid fishes from Monterey Bay, California." Proceedings of the United States National Museum 47(2049), 135-137. https://doi.org/10.5479/si.00963801.47-2049.135.

View This Item Online: https://www.biodiversitylibrary.org/item/32860

DOI: https://doi.org/10.5479/si.00963801.47-2049.135

Permalink: https://www.biodiversitylibrary.org/partpdf/31716

\section{Holding Institution}

Smithsonian Libraries

\section{Sponsored by}

Smithsonian

\section{Copyright \& Reuse}

Copyright Status: NOT_IN_COPYRIGHT

This document was created from content at the Biodiversity Heritage Library, the world's largest open access digital library for biodiversity literature and archives. Visit BHL at https://www.biodiversitylibrary.org. 